\title{
OPEN Seasonal pattern of food habits of large herbivores in riverine alluvial grasslands of Brahmaputra floodplains, Assam
}

\author{
Anita Devi, Syed Ainul Hussain $₫$, Monika Sharma, Govindan Veeraswami Gopi \& \\ Ruchi Badola
}

Jarman-Bell (1974) hypothesized that in the dry savanna of Africa, small-bodied herbivores tend to browse more on forage with high protein and low fibre content. This implies browsing on high nutritive forage by meso-herbivores, and grazing and mixed feeding on coarse forage by mega-herbivores. We tested this hypothesis in the riverine alluvial grasslands of the Kaziranga National Park (KNP), where seasonal flood and fire play an important role in shaping the vegetation structure. We analyzed the feeding habits and quality of major forage species consumed by three mega-herbivores, viz. greater one-horned rhino, Asian elephant, and Asiatic wild buffalo, and three meso-herbivores, viz. swamp deer, hog deer, and sambar. We found that both mega and meso-herbivores were grazers and mixed feeders. Overall, 25 forage plants constituted more than $70 \%$ of their diet. Among monocots, family Poaceae with Saccharum spp. (contributing $>9 \%$ of the diet), and, among dicots, family Rhamnaceae with Ziziphus jujuba (contributing $>4 \%$ of the diet) fulfilled the dietary needs. In the dry season, the concentration of crude protein, neutral detergent fibre, calcium, sodium, and phosphorous varied significantly between monocots and dicots, whereas only calcium and sodium concentrations varied significantly in the wet season. Dicots were found to be more nutritious throughout the year. Compared to the dry season, the monocots, viz. Alpinia nigra, Carex vesicaria, Cynodon dactylon, Echinochloa crus-galli, Hemarthria compressa, Imperata cylindrica, and Saccharum spp., with their significantly high crude protein, were more nutritious during the wet season. Possibly due to the availability of higher quality monocots in the wet season, both mega and meso-herbivores consume it in high proportion. We concluded that the Jarman-Bell principle does not apply to riverine alluvial grasslands as body size did not explain the interspecific dietary patterns of the mega and meso-herbivores. This can be attributed to seasonal floods, habitat and forage availability, predation risk, and management practices such as controlled burning of the grasslands. The ongoing succession and invasion processes, anthropogenic pressures, and lack of grassland conservation policy are expected to affect the availability of the principal forage and suitable habitat of large herbivores in the Brahmaputra floodplains, which necessitates wet grassland-based management interventions for the continued co-existence of large herbivores in such habitats.

Understanding the niche of an animal is crucial for understanding the community dynamics of dependent consumers. Foraging is one of the fundamental elements of a niche ${ }^{1,2}$. In sympatric herbivores, the foraging patterns provide insights into the utilization patterns of the occupied habitat, which is important for making assumptions about the behaviour, physiology, morphology, and population dynamics of the predators, prey, and competitors ${ }^{3}$. In the early 1960s, the ecological succession and separation theory described forage resource partitioning as the reason for the co-existence of herbivores of different body sizes ${ }^{4-6}$. Bell ${ }^{7}$ and Jarman ${ }^{8}$ explained the co-existence of mega and meso-herbivores as a function of body mass and digestive physiology, whereas Hofmann and Stewart ${ }^{9}$ reasoned digestive physiology as the explanation for foraging style. The Jarman-Bell principle emphasized that the quality and quantity of large herbivore diet correlates with their body size; specifically, the diet quality decreases as body size increases. Depending on body size, herbivores consume a large or small amount 
of coarse forage to fulfil their body requirement ${ }^{8,10}$. The allometric theory ${ }^{11}$ and digestive physiology ${ }^{12}$ explained the mechanism behind the Jarman-Bell principle. The allometric theory explained that the length of the digestive tract is directly proportional to the body mass, and consequently, the metabolism rate is inversely proportional to the body mass. Demment and Van Soest ${ }^{12}$ provided evidence that the capability to digest coarse forage increases with the increase in gut capacity. Hence, the digestive capability of mega and meso-herbivores plays a crucial role in their dietary selection ${ }^{13,14}$. Thus, depending on both nutritional (crude protein content, mineral content, and digestibility) and anti-nutritional parameters (plant secondary metabolites or fibre), meso-herbivores need to browse on forage with high protein and low fibre content. In contrast, mega-herbivores may feed on forage with low protein and high fibre content ${ }^{15,16}$.

The preponderance of the studies that examined the ecology of large assemblages of sympatric herbivores and tested the body mass principle have primarily emerged from Africa and North America ${ }^{17,18}$. The studies conducted to test the Jarman-Bell principle in the African savannas ${ }^{19-24}$ and the protected areas of North America ${ }^{21}$ primarily covered dry tropical grasslands, forests, or savannas. These studies provided insight into resource segregation, competition, and habitat utilization along the temporal ${ }^{19,20}$, and spatial gradients ${ }^{21-25}$.

Of the 19 terrestrial mammalian herbivore species with a body mass greater than $100 \mathrm{~kg}$, in South and SouthEast Asia, 14 are found in India ${ }^{26}$. Though the herbivore species found in India are distinct from those in Africa, the similarities in the diverse range of body sizes, from mega-herbivores like elephant, with a body weight of 3000 to $5400 \mathrm{~kg}$, to meso-herbivores like mouse deer, with a body weight of 2 to $4 \mathrm{~kg}$, provide the opportunity to test the Jarman-Bell principle ${ }^{6,27,28}$. The literature available to understand the science of wild large herbivore foraging ecology at the community level is limited from Asia ${ }^{29}$. Most of the research conducted in India studied up to four wild herbivore species and contributed mostly to their biology and ecology $\mathrm{y}^{6,29}$. Ahrestani ${ }^{6}$ tested the Jarman-Bell principle for chital (Axis axis), sambar (Rusa unicolor), gaur (Bos gaurus), and elephant (Elephas maximus) in the dry tropical forests of India, where he concluded that body size does not explain the graze to browse ratio of sambar and chital. Wegge et al. ${ }^{29}$ tested the Jarman-Bell principle for rhinoceros (Rhinoceros unicornis), swamp deer (Rucervus duvaucelii), and hog deer (Axis porcinus) in riverine alluvial grasslands of Nepal, where they concluded that the body size does not explain the consumption of higher graminoids by smaller herbivores. There is little understanding of how this principle explains the foraging pattern and resource partitioning among large herbivores along the temporal and spatial gradients in the riverine alluvial grassland ecosystem. Large assemblages of mega and meso-herbivores in the Brahmaputra valley provide an opportunity to examine the applicability of the Jarman-Bell principle in a moist grassland ecosystem, which is subjected to anthropogenic pressure and is vulnerable to climate change.

In the last few decades, climate change and habitat loss have impacted biological systems. It is estimated that since $1970,58 \%$ of animal populations have faced the threat of extinction ${ }^{30-32}$. Climate change poses a serious threat to herbivores directly by influencing rainfall and temperature, and indirectly through the occurrence of extreme climatic events such as fires, floods, and droughts, which may affect the availability and quality of forage and threaten their fitness, survival, migration, and reproductive success ${ }^{33,34}$. Globally, riverine alluvial grasslands in floodplains are threatened, primarily due to fragmentation and degradation of such habitats ${ }^{35}$. In the Brahmaputra valley, remnant riverine alluvial grasslands found mainly in and around protected areas are restricted in their spatial extent thereby, limiting the range of obligate large herbivores ${ }^{35,36}$. The decreasing trend of riverine alluvial grasslands has resulted in low species richness of large herbivore assemblages; consequently, the sample size to validate community ecology theory is often inadequate, which prompts this study ${ }^{35}$.

Based on feeding styles, herbivores are generally categorized as grazers (feeding mainly on graminoids or monocots), browsers (feeding mainly on browse or dicots), or mixed feeders (feeding on both monocots and dicots, according to their availability). Any change in the consumption of monocots (grazing) and dicots (browsing) results in changed diet compositions. Experimental studies conducted in the Serengeti-Mara ecosystem in the last 100 years have highlighted the importance of mega and meso-herbivores in converting open grassland to dense woodland and back to grassland ${ }^{37}$. Thus, in succession, both the absence and presence of mega and mesoherbivores plays an important role ${ }^{38,39}$. Browsers and mixed-feeders generally affect the savannas of Africa ${ }^{40}$.

Even though the Brahmaputra floodplains in India harbour a large assemblage of mega and meso-herbivores, there is a dearth of studies on their community ecology. The limited information that is available is from Pobitora Wildlife Sanctuary ${ }^{41,42}$, Rajiv Gandhi Orang National Park ${ }^{43}$, Manas National Park ${ }^{44}$, and Kaziranga National Park (KNP) ${ }^{45-48}$, and is based on two to three species. Besides, there is little understanding of the habitat dynamics and the impact of seasonal change on the moist alluvial grasslands and their associated fauna. The riverine alluvial grasslands of KNP in the Brahmaputra floodplains are one of the few strongholds of several threatened species including the greater one-horned rhino (R. unicornis), Asian elephant (E. maximus), Asiatic wild buffalo (Bubalus arnee), swamp deer ( $R$. duvaucelii), hog deer (A. porcinus), and sambar (R. unicolor), which necessitates their conservation (Fig. 1). This study was carried out to gain insight into how the body mass principle explains the co-existence of these six mega and meso-herbivores in riverine alluvial grasslands with respect to their diet composition and nutritional quality of principal forage. For the present study, based on the literature on body size and diet composition, the less selective mega-herbivores with very large body sizes ( $>1000 \mathrm{~kg})$, viz. rhino, elephant, and buffalo, were categorized as coarse feeders ${ }^{13,49}$. Whereas the more selective meso-herbivores with small to medium body sizes ( $>5 \mathrm{~kg}$ and $<500 \mathrm{~kg}$ ), viz. swamp deer, hog deer, and sambar, were categorized as soft feeders ${ }^{14,50,51}$.

Based on the information from riverine alluvial grasslands ${ }^{18,29}$, we predicted that both mega and mesoherbivores would consume more graze-based diet in the wet season $\left(\mathrm{H}_{1}\right)$, and compared to dry season, the principal monocot forage of mega and meso-herbivores would be more nutritious in the wet season $\left(\mathrm{H}_{2}\right)$. This study aims to provide an overview of the feeding habits of mega and meso-herbivores with the following research questions: (1) is there any difference in the diet compositions of the mega and meso-herbivores in each season in terms of (a) monocot and dicot, (b) the six categories of growth form, viz. grass, sedge, herb, shrub, climber and 


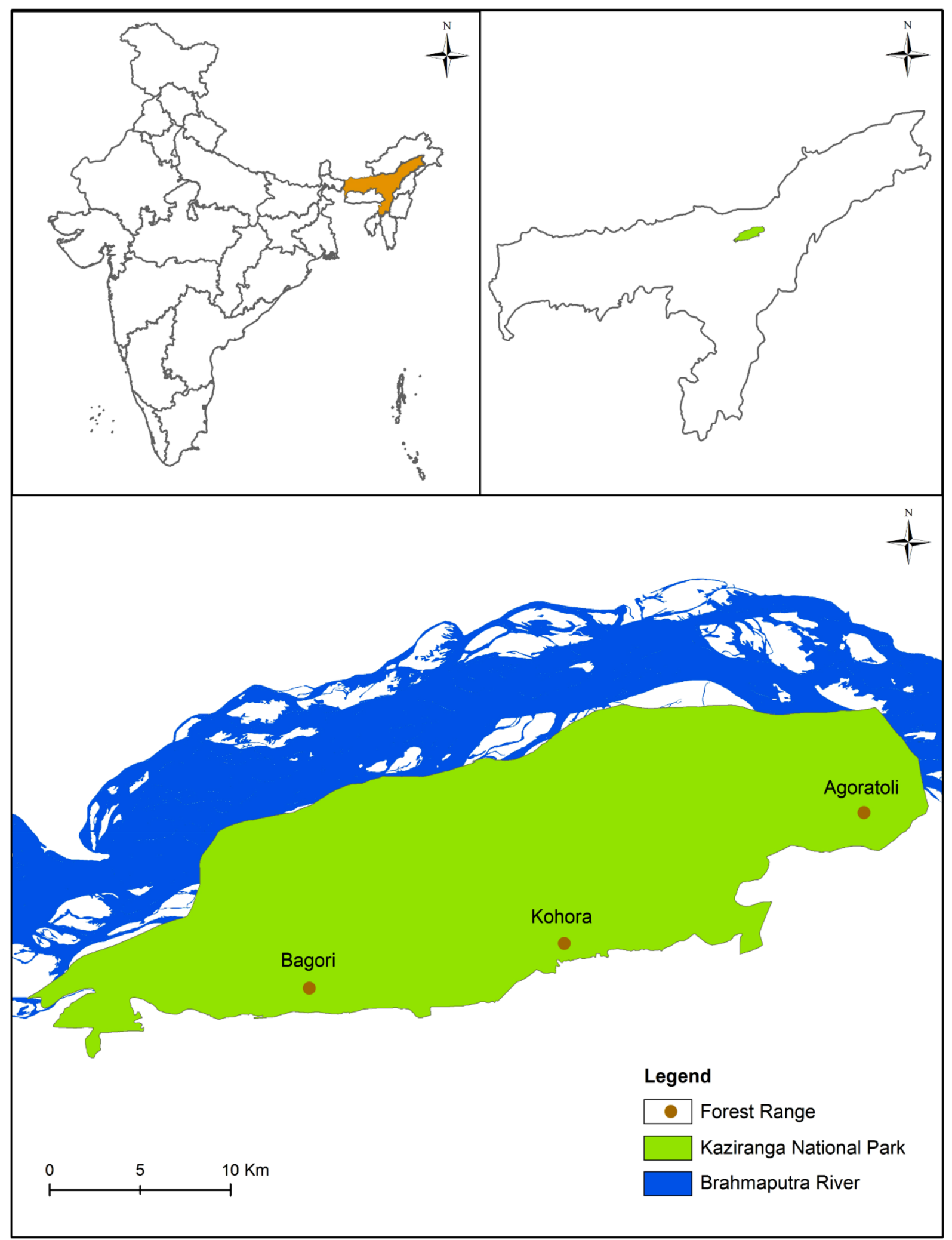

Figure 1. Map showing the location of the riverine alluvial grasslands in Kaziranga National Park, Assam. The map was created using ArcGIS v.10.2.2 software developed by ESRI (https://www.esri.com). 


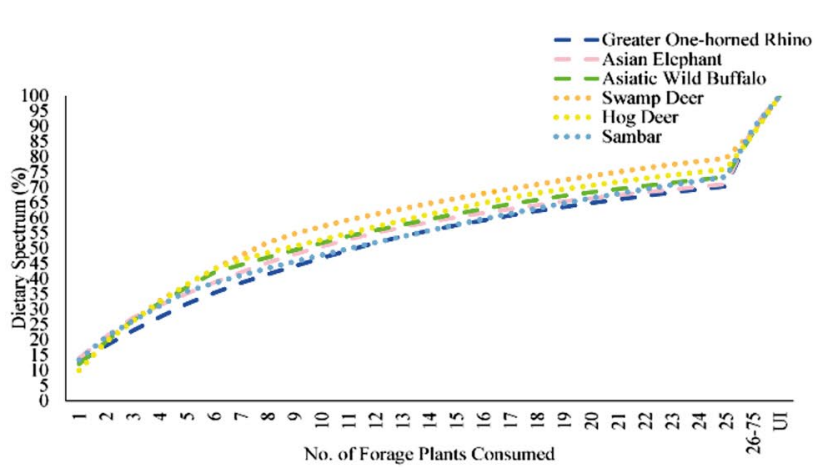

(a)

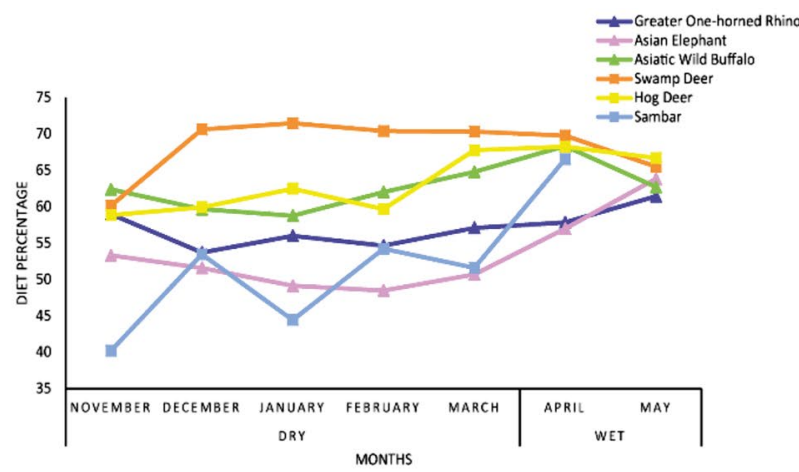

(b)

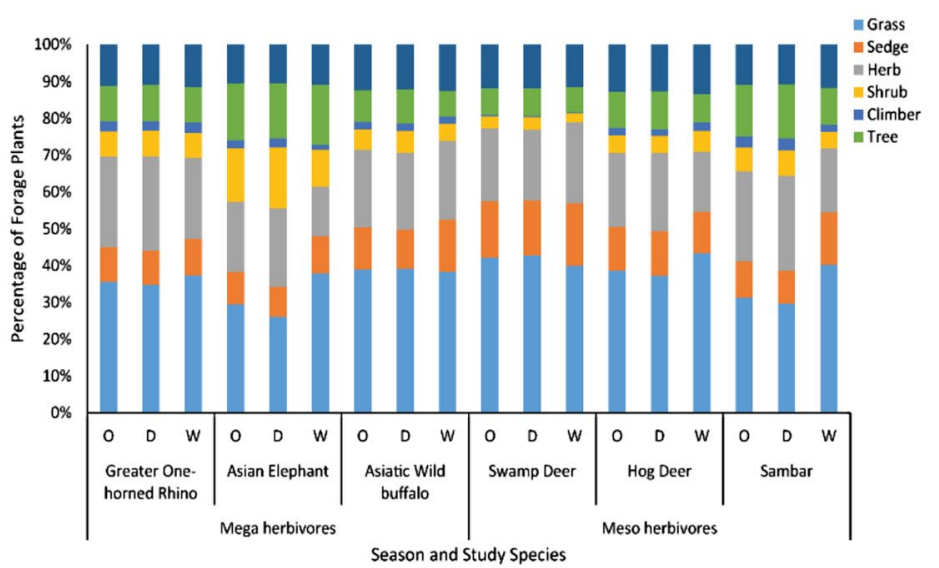

(c)

Figure 2. Graph showing (a) overall dietary spectrum (\%) of major contributing forage plants to the diet, (b) monthly consumption of monocots by the six large herbivore species. A high value of the diet percentage suggests a graze-based diet, whereas a low value of the diet percentage suggests a browse-based diet and (c) diet composition of mega and meso-herbivores in terms of six growth forms of different forage plants in Kaziranga National Park, Assam.

tree, and (c) the forage plant species contributing to the diets of the mega and meso-herbivores; (2) is there any difference in the seasonal nutrient parameters of major forage plants consumed by mega and meso-herbivores; and (3) which nutrient factors govern the forage utilization by mega and meso-herbivores.

\section{Results}

Dietary spectrum. Throughout the year, 25 major forage plants constituted more than $70 \%$ of the diet of large herbivores (Fig. 2a), specifically $79.48 \%$ of swamp deer's, $75.87 \%$ of hog deer's, $73.42 \%$ of sambar's, $73.38 \%$ of buffalo's, $71.04 \%$ of elephant's, and $70.29 \%$ of rhino's diet. The 22 principal forage plant species, namely Saccharum spp., Echinochloa crus-galli, Cynodon dactylon, Ziziphus jujuba, Hemarthria compressa, Alpinia nigra, Carex vesicaria, Kyllinga brevifolia, Mallotus nudiflorus, Lippia alba, Fimbristylis aestivalis, Amaranthus spinosus, Ageratum conyzoides, Duchesnea indica, Calamus tenuis, Oxalis corniculata, Imperata cylindrica, Acmella uliginosa, Amaranthus viridis, Dillenia indica, Solanum americanum, and Setaria pumila contributed more than $2 \%$ each. The highest number of identified principal forage species $(n=22)$ were recorded for hog deer $(n=14 ; 61.15 \%)$ followed by rhino $(n=13 ; 53.89 \%)$, elephant $(n=12 ; 55.00 \%)$, sambar $(n=12 ; 51.90 \%)$, buffalo $(\mathrm{n}=11 ; 53.97 \%)$, and swamp deer $(\mathrm{n}=11 ; 59.29 \%)$.

Diet comparison. The mega and meso-herbivores consumed more monocots during the wet season than the dry season (Fig. 2b). There were significant seasonal differences in the consumption of monocots \& monocots, dicots \& dicots, and monocots \& dicots among the six large herbivores. Between the mega and meso-herbivores, there were significant seasonal differences in the consumption of dicots \& dicots and monocots \& dicots, and no significant seasonal difference in the consumption of monocots \& monocots. Among the six growth forms, grasses were dominant in the diet of all the six herbivores (Fig. 2c). There were significant seasonal differences in the consumption of grasses and herbs among the six large herbivores, and no significant differences in the consumption of sedges, shrubs, climbers, and trees. Between the mega and meso-herbivores, there were significant seasonal differences in the consumption of grasses and trees, and no significant seasonal differences in the consumption of sedges, herbs, shrubs, and climbers. A total of 31 families of forage plants were identified in the diet of the mega-herbivores and 29 in the diet of the meso-herbivores. Overall, the Bipartite Ecological 


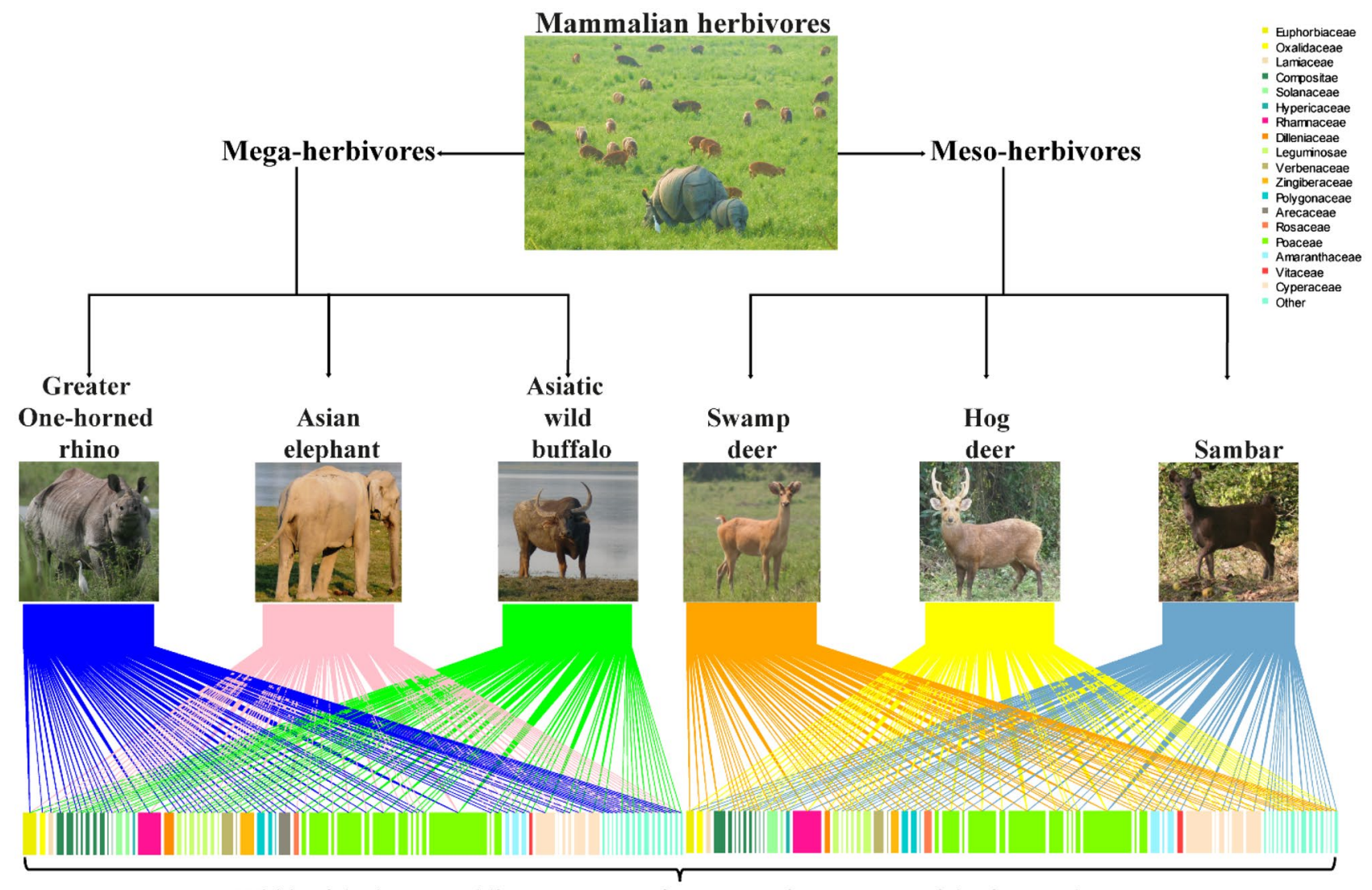

Width of the boxes and lines represents frequency of occurrence of the forage plants

Figure 3. Flow diagram representing the overall bipartite ecological network, which illustrates the diet composition of mega and meso-herbivores. Study species (upper boxes) connected by lines to forage plants (lower boxes) are coloured by family. The width of the lines and lower boxes represent the frequency of occurrence of the forage plants and their respective families in the diet of mega and meso-herbivores in Kaziranga National Park, Assam.

Network (BEN) shows that the members of the family Poaceae contributed the most to the diet of mega and meso-herbivores (Fig. 3). It also shows that the contribution of forage species belonging to the families Poaceae and Cyperaceae, to the diet of both mega and meso-herbivores, increased from dry (34.33 to 57.70\%) to wet season (47.27 to 57.06\%) (Fig. 4a,b). C. tenuis (family Arecaceae) was consumed mostly by the elephant. BEN further revealed that the mean number of shared forage plants in the diet of both mega and meso-herbivores in the dry and wet seasons were 57.6 and 51, respectively. The tall grass Saccharum spp. constituted a major part of the diet of mega and meso-herbivores during the wet season. A significant seasonal difference in the consumption of Saccharum spp. was observed among the six large herbivores, whereas no significant difference was observed in the consumption of Saccharum spp. between the mega and meso-herbivores during different seasons.

Monocots dominated the diet of both mega and meso-herbivores throughout the year (Table 1). Only elephant and sambar consumed a significantly higher proportion of monocots than dicots in the wet season (Table 2). In contrast, there was no significant seasonal difference in the consumption of monocots \& dicots by rhino, buffalo, swamp deer, and hog deer. Compared to the dry season, the six herbivores consumed a significantly higher proportion of monocots and a significantly lower proportion of dicots in the wet season.

Grasses dominated the diet of both mega and meso-herbivores throughout the year (Fig. 2c). Between the dry and wet seasons, the six herbivores consumed significantly different proportions of grasses, herbs, climbers, and trees; and only elephant and sambar consumed a significantly different proportion of shrubs. Excluding hog deer, the study species consumed significantly different proportions of sedges (Table 2).

Among the monocots, Saccharum spp., E. crus-galli, C. dactylon, H. compressa, and A. nigra contributed the most to the rhino diet, while among the dicots, Z. jujuba, M. nudiflorus, L. alba, A. spinosus, and A. conyzoides contributed the most (Supplementary Table S1). In the elephant diet, Saccharum spp., C. tenuis, C. vesicaria, E. crus-galli, and $H$. compressa contributed the most among the monocots, and Z. jujuba, M. nudiflorus, D. indica, L. alba, and A. conyzoides contributed the most among the dicots (Supplementary Table S2). In the buffalo diet, Saccharum spp., H. compressa, E. crus-galli, C. vesicaria, and C. dactylon contributed the most among the monocots and, Z. jujuba, O. corniculata, L. alba, S. americanum, and M. nudiflorus contributed the most among the dicots (Supplementary Table S3). In the diet of swamp deer, among the monocots, H. compressa, Saccharum spp., E. crus-galli, C. vesicaria, and I. cylindrica contributed the most, and among the dicots, Z. jujuba, A. uliginosa, L. alba, S. americanum, and O. corniculata contributed the most (Supplementary Table S4). In the hog deer diet, H. compressa, Saccharum spp., E. crus-galli, C. vesicaria, and C. dactylon contributed the most among the 

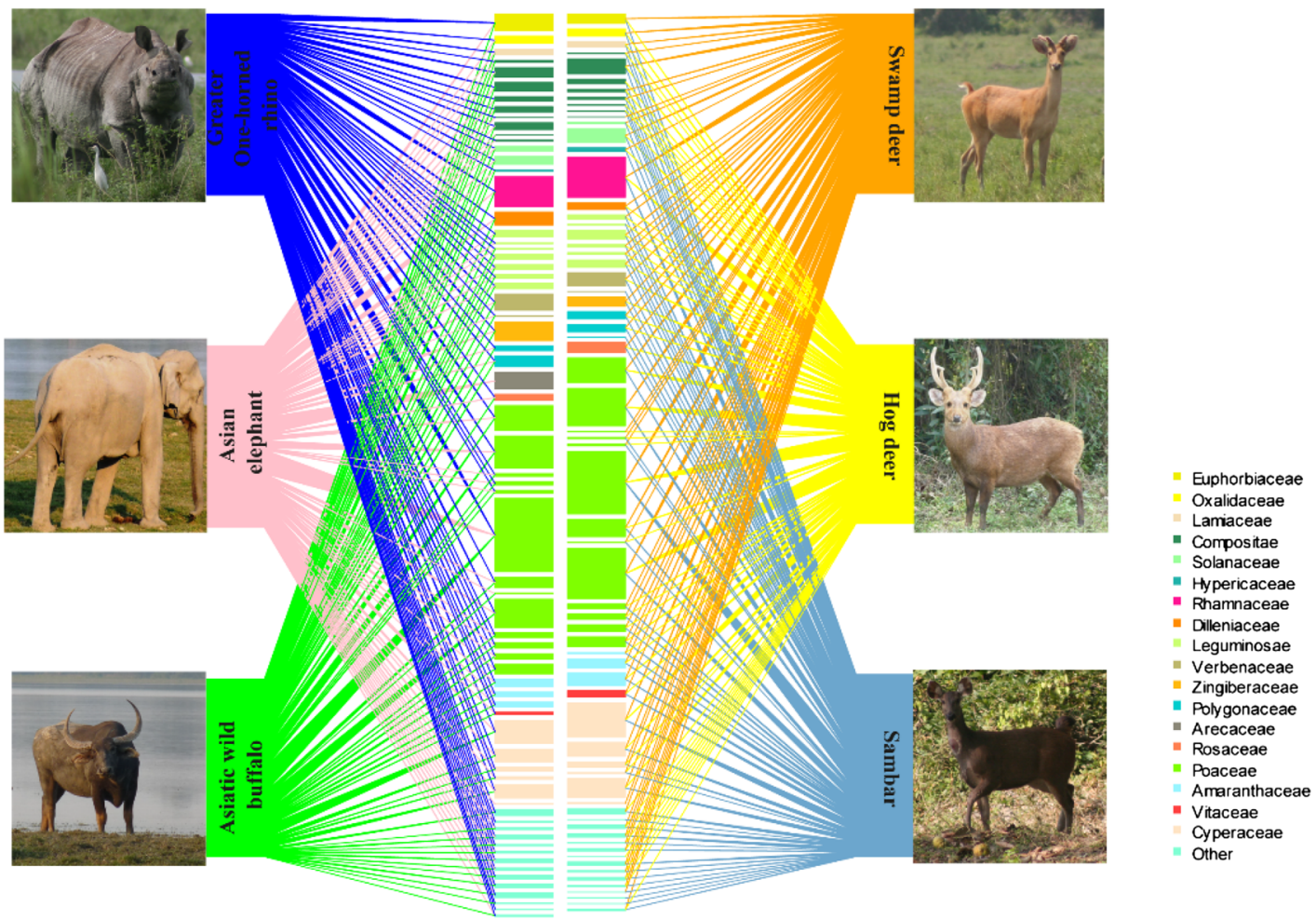

(a)
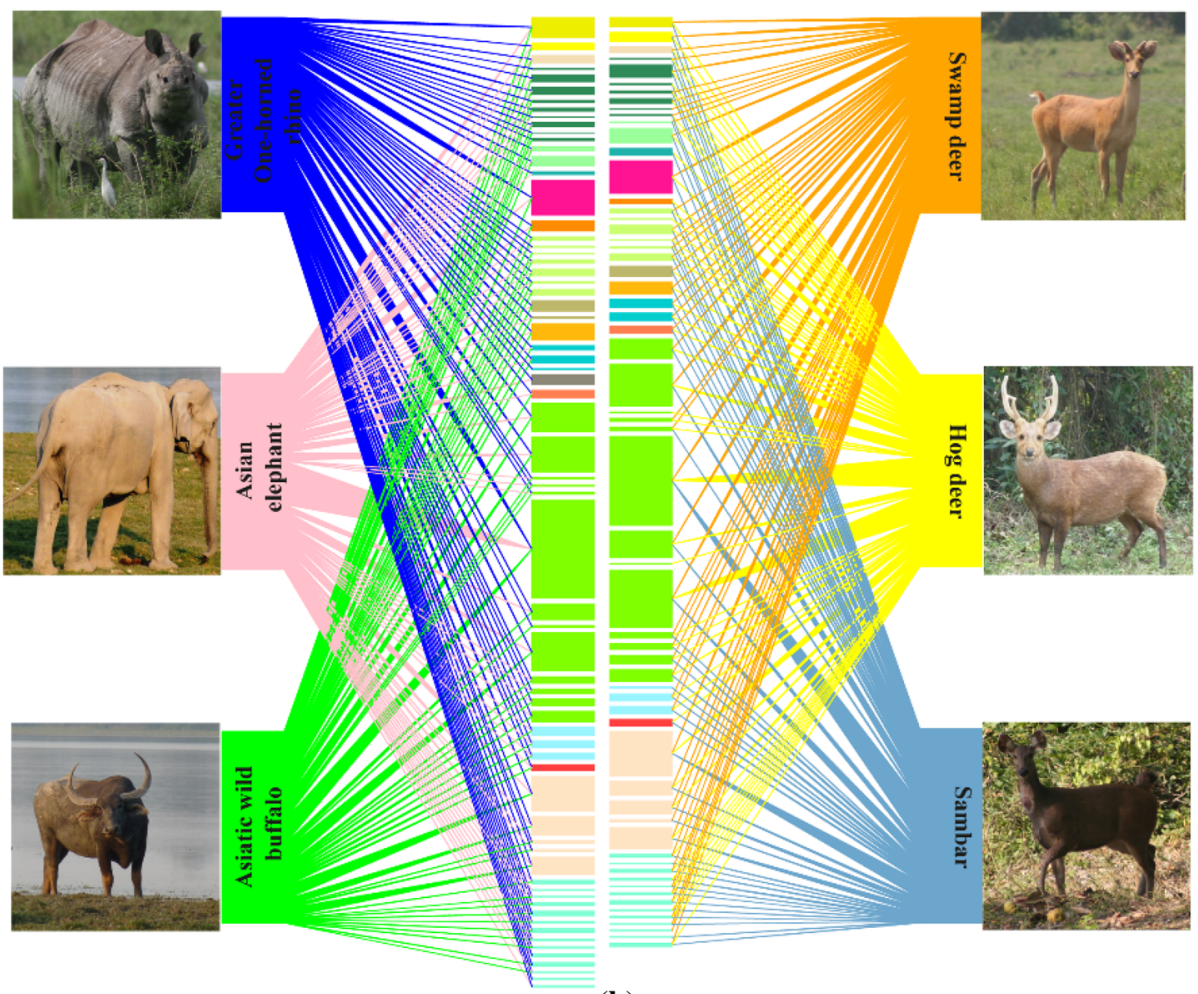

Euphorbiaceae Oxalidaceae

Lamiaceae

- Solanaceae

= Hypericaceae

- Rhamaceae

- Dilleniaceae

Leguminosae

Verbenaceae

Zingiberaceae

Polygonacea

- Arecaceae

- Rosaceae

- Poaceae

Amaranthacea

- Vitaceae

Cyperaceae

(b)

Figure 4. The bipartite ecological network illustrates the diet composition of mega and meso-herbivores. Study species (upper boxes) connected by lines to forage plants (lower boxes) are coloured by family. The width of the lines and lower boxes represent the frequency of occurrence of the forage plants and their respective families in the diet of mega and meso-herbivores in (a) dry and (b) wet season in Kaziranga National Park, Assam. 


\begin{tabular}{|c|c|c|c|c|c|c|c|c|c|c|c|c|c|c|}
\hline \multirow[b]{2}{*}{ Study species } & \multicolumn{9}{|c|}{ Fragments } & \multicolumn{5}{|c|}{ Forage plants } \\
\hline & $\mathbf{I}$ & I \% & UI & UI \% & Total & $\mathbf{M}$ & $\mathbf{M} \%$ & $\mathbf{D}$ & $\mathrm{D} \%$ & I & I \% & UI & UI \% & Total \\
\hline Greater One-horned Rhino & 7519 & 88.99 & 930 & 11.01 & 8449 & 4827 & 57.13 & 3622 & 42.87 & 69 & 88.99 & 55 & 11.01 & 124 \\
\hline Asian Elephant & 7184 & 89.55 & 838 & 10.45 & 8022 & 4295 & 53.54 & 3727 & 46.46 & 67 & 89.55 & 38 & 10.45 & 105 \\
\hline Asiatic Wild Buffalo & 6403 & 87.77 & 892 & 12.23 & 7295 & 4567 & 62.60 & 2728 & 37.40 & 62 & 87.77 & 34 & 12.23 & 96 \\
\hline Swamp Deer & 6595 & 88.23 & 880 & 11.77 & 7475 & 5111 & 68.37 & 2364 & 31.63 & 59 & 88.23 & 31 & 11.77 & 90 \\
\hline Hog Deer & 6419 & 87.23 & 940 & 12.77 & 7359 & 4628 & 62.89 & 2731 & 37.11 & 59 & 87.23 & 32 & 12.77 & 91 \\
\hline Sambar & 6277 & 89.19 & 761 & 10.81 & 7038 & 3622 & 51.46 & 3416 & 48.54 & 63 & 89.19 & 29 & 10.81 & 92 \\
\hline
\end{tabular}

Table 1. Identified and unidentified fragments and forage plants recorded in the diet of mega and mesoherbivores throughout the year during 2013-15 in Kaziranga National Park, Assam. I identified, UI unidentified, $M$ monocots, $D$ Dicots.

\begin{tabular}{|c|c|c|c|c|c|c|c|c|c|c|c|c|c|c|c|c|c|c|c|c|c|c|c|c|}
\hline \multirow{2}{*}{$\begin{array}{l}\text { Forage } \\
\text { category }\end{array}$} & \multicolumn{3}{|c|}{$\begin{array}{l}\text { Six large } \\
\text { herbivores }\end{array}$} & \multicolumn{3}{|c|}{$\begin{array}{l}\text { Mega and meso- } \\
\text { herbivore }\end{array}$} & \multicolumn{3}{|c|}{$\begin{array}{l}\text { Greater one- } \\
\text { horned rhino }\end{array}$} & \multicolumn{3}{|c|}{ Asian elephant } & \multicolumn{3}{|c|}{$\begin{array}{l}\text { Asiatic wild } \\
\text { buffalo }\end{array}$} & \multicolumn{3}{|c|}{ Swamp deer } & \multicolumn{3}{|c|}{ Hog deer } & \multicolumn{3}{|l|}{ Sambar } \\
\hline & $\chi^{2}$ & df & $\mathbf{p}$ & $\chi^{2}$ & df & $\mathbf{p}$ & $\chi^{2}$ & df & $\mathbf{p}$ & $\chi^{2}$ & df & $\mathbf{p}$ & $\chi^{2}$ & df & $\mathbf{p}$ & $\chi^{2}$ & df & $\mathbf{p}$ & $\chi^{2}$ & df & $\mathbf{p}$ & $\chi^{2}$ & df & p \\
\hline$M \& M$ & 11.29 & 5 & 0.05 & 3.19 & 1 & 0.07 & 65.60 & 1 & 0.00 & 46.59 & 1 & 0.00 & 71.36 & 1 & 0.00 & 88.78 & 1 & 0.00 & 68.19 & 1 & 0.00 & 99.11 & 1 & 0.00 \\
\hline $\mathrm{D} \& \mathrm{D}$ & 31.21 & 5 & 0.00 & 4.69 & 1 & 0.03 & 63.48 & 1 & 0.00 & 86.58 & 1 & 0.00 & 57.97 & 1 & 0.00 & 39.80 & 1 & 0.00 & 62.11 & 1 & 0.00 & 173.97 & 1 & 0.00 \\
\hline$M \& D$ & 56.63 & 5 & 0.00 & 6.59 & 1 & 0.01 & 0.64 & 1 & 0.43 & 5.63 & 1 & 0.02 & 1.03 & 1 & 0.31 & 0.08 & 1 & 0.78 & 2.00 & 1 & 0.16 & 11.06 & 1 & 0.00 \\
\hline Grass & 14.81 & 5 & 0.01 & 4.18 & 1 & 0.04 & 37.64 & 1 & 0.00 & 14.29 & 1 & 0.00 & 47.88 & 1 & 0.00 & 68.79 & 1 & 0.00 & 35.64 & 1 & 0.00 & 62.04 & 1 & 0.00 \\
\hline Herb & 25.28 & 5 & 0.00 & 0.23 & 1 & 0.63 & \begin{tabular}{|l|}
10.88 \\
\end{tabular} & 1 & 0.00 & 7.23 & 1 & 0.01 & 8.45 & 1 & \begin{tabular}{|l|}
0.00 \\
\end{tabular} & 16.64 & 1 & 0.00 & \begin{tabular}{|l|}
19.05 \\
\end{tabular} & 1 & 0.00 & 16.29 & 1 & 0.00 \\
\hline Tree & 10.45 & 5 & 0.06 & 4.56 & 1 & 0.03 & \begin{tabular}{|l|}
47.02 \\
\end{tabular} & 1 & 0.00 & 50.29 & 1 & 0.00 & 24.97 & 1 & 0.00 & 13.26 & 1 & 0.00 & 39.68 & 1 & 0.00 & 85.92 & 1 & 0.00 \\
\hline Sedge & 2.44 & 5 & \begin{tabular}{|l|}
0.79 \\
\end{tabular} & \begin{tabular}{|l|}
1.34 \\
\end{tabular} & 1 & 0.25 & 8.33 & 1 & \begin{tabular}{|l|}
0.00 \\
\end{tabular} & 37.69 & 1 & 0.00 & 15.51 & 1 & \begin{tabular}{|l|}
0.00 \\
\end{tabular} & 4.55 & 1 & 0.03 & 3.46 & 1 & \begin{tabular}{|l|}
0.06 \\
\end{tabular} & 21.56 & 1 & 0.00 \\
\hline Shrub & 6.79 & 5 & 2.37 & 0.06 & 1 & 0.81 & 3.56 & 1 & 0.06 & 9.00 & 1 & 0.00 & 3.27 & 1 & \begin{tabular}{|l|}
0.07 \\
\end{tabular} & 2.78 & 1 & 0.10 & 1.14 & 1 & \begin{tabular}{|l|}
0.29 \\
\end{tabular} & 10.89 & 1 & 0.00 \\
\hline Climber & 4.30 & 5 & 0.51 & 0.22 & 1 & \begin{tabular}{|l|}
0.64 \\
\end{tabular} & \begin{tabular}{|l|}
10.24 \\
\end{tabular} & 1 & \begin{tabular}{|l|}
0.00 \\
\end{tabular} & 15.71 & 1 & 0.00 & \begin{tabular}{|l|}
15.00 \\
\end{tabular} & 1 & \begin{tabular}{|l|}
0.00 \\
\end{tabular} & 9.00 & 1 & 0.00 & 20.43 & 1 & \begin{tabular}{|l|}
0.00 \\
\end{tabular} & 47.82 & 1 & 0.00 \\
\hline $\begin{array}{l}\text { Sac- } \\
\text { charum } \\
\text { spp }^{\mathrm{a}}\end{array}$ & 16.62 & 5 & 0.01 & 1.61 & 1 & 0.21 & - & - & - & - & - & - & - & - & - & - & - & - & - & - & - & - & - & - \\
\hline
\end{tabular}

Table 2. Chi-square test for food choices of the mega and meso-herbivores between dry and wet season (M-monocots; D-dicots) during 2013-15 in Kaziranga National Park, Assam. a Principal forage of mega and meso-herbivores.

monocots, and Z. jujuba, A. viridis, D. indica, S. americanum, and L. alba contributed the most among the dicots (Supplementary Table S5). In the diet of sambar, among the monocots, Saccharum spp., E. crus-galli, H. compressa, C. vesicaria, and I. cylindrica contributed the most, and among the dicots, Z. jujuba, A. uliginosa, S. americanum, D. indica, and M. nudiflorus contributed the most (Supplementary Table S6).

Forage quality. Throughout the year, the highest crude protein (CP) was recorded for E. crus-galli (12.16\%) and lowest for Saccharum spp. (6.02\%), among the monocots. In the dry season, the highest CP was recorded for C. tenuis (10.87\%) and lowest for Saccharum spp. (4.75\%), whereas in the wet season, the highest CP was recorded for E. crus-galli (16.47\%) and lowest for A. nigra (9.11\%) (Supplementary Tables S7-S9). Compared to the dry season, the monocots showed a higher mean concentration of $\mathrm{CP}$, calcium $(\mathrm{Ca})$, magnesium $(\mathrm{Mg})$, sodium $(\mathrm{Na})$, potassium $(\mathrm{K})$, and phosphorous $(\mathrm{P})$, and a lower mean concentration of ash content $(\mathrm{AC})$, acid detergent lignin $(\mathrm{ADL})$, acid detergent fibre $(\mathrm{ADF})$, and neutral detergent fibre (NDF) in the wet season. There were significant differences in $\mathrm{AC}, \mathrm{CP}, \mathrm{ADL}, \mathrm{Na}, \mathrm{K}$, and $\mathrm{P}$ content (Mann-Whitney, $\mathrm{p}<0.05$ ) in monocots between the dry and wet seasons (Supplementary Table S10). The most consumed monocot species in mega and meso-herbivores diet, viz. Saccharum spp., showed significant differences in AC, CP, ADL, and K concentrations (Mann-Whitney, p <0.05), between the dry and wet seasons. The monocots, A. nigra, C. vesicaria, C. dactylon, E. crus-galli, H. compressa, and I. cylindrica showed a significant difference in CP concentration (Mann-Whitney, $\mathrm{p}<0.05)$, between the dry and wet seasons. Among the dicots, throughout the year and in both the dry and wet seasons, the highest CP concentration was recorded for A. viridis and lowest for D. indica. Compared to the dry season, dicots showed a higher mean concentration of $\mathrm{ADF}, \mathrm{NDF}, \mathrm{Mg}, \mathrm{Na}, \mathrm{K}$, and $\mathrm{P}$, and a lower mean concentration of $\mathrm{CP}, \mathrm{ADL}$, and $\mathrm{Ca}$ in the wet season. However, there was no significant difference in the nutrient concentration of dicots between dry and wet seasons. In dicots, the most consumed forage species in the diet of mega and meso-herbivores, viz. Z. jujuba, showed a significant difference only in ADL concentration (MannWhitney, $\mathrm{p}<0.05)$, between the dry and wet seasons.

Throughout the year and in both the dry and wet seasons, dicots with their high CP and mineral concentrations were more nutritious than monocots. While there were significant changes in the nutritional quality parameters of monocots from the dry to wet season, no significant seasonal changes in the nutritional quality of dicots were recorded (Supplementary Table S10). Throughout the year, there were significant differences in CP, ADL, 

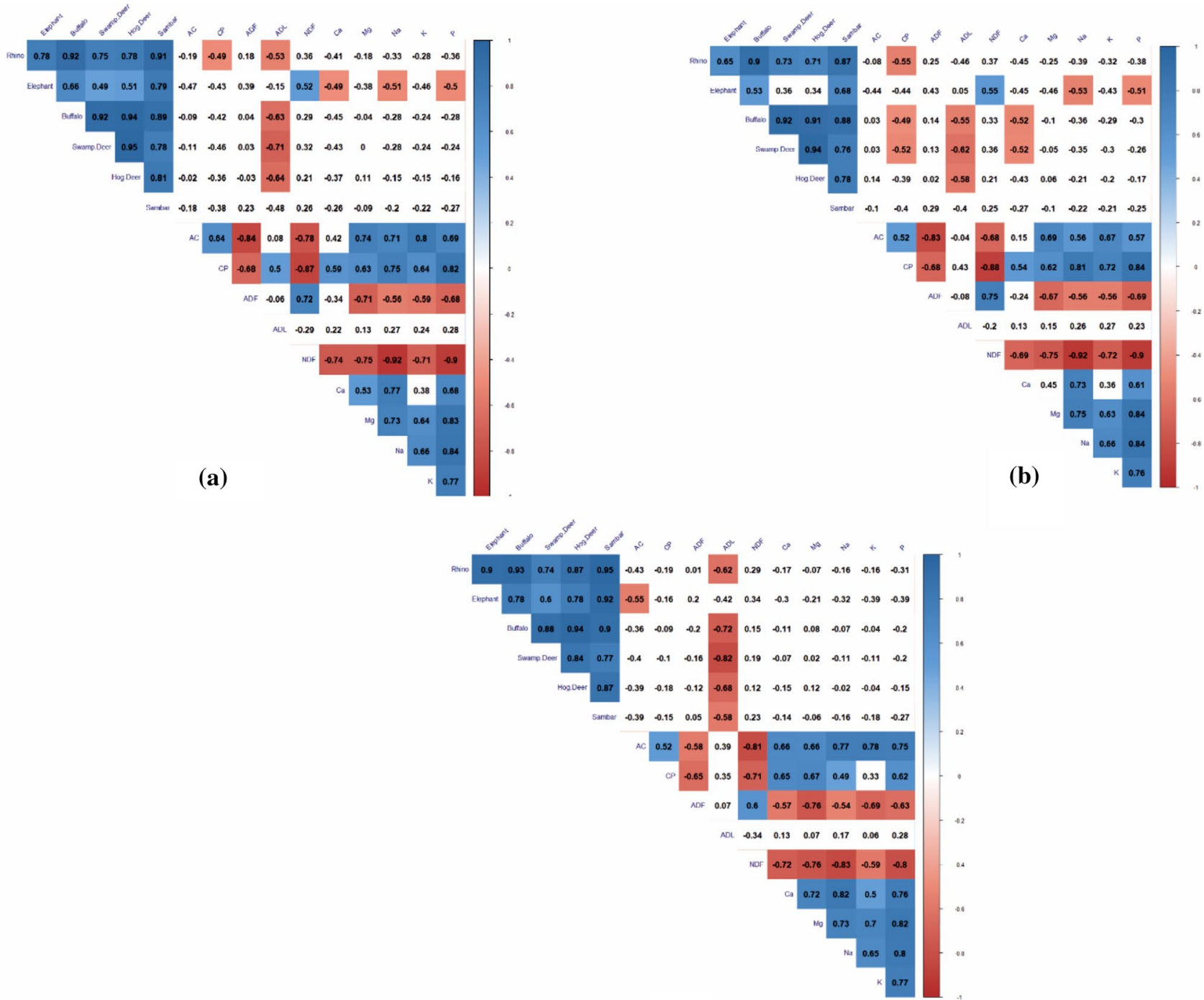

(c)

Figure 5. Correlogram showing the relationship between nutrient parameters and the major forage consumed by mega and meso-herbivores in (a) overall, (b) dry and (c) wet season. The values within white boxes represent the insignificant correlation ( $p>0.05)$ whereas the values within red (negative correlation) and blue (positive correlation) boxes represent the significant correlation $(\mathrm{p}<0.05)$.

$\mathrm{NDF}, \mathrm{Ca}, \mathrm{Na}$, and $\mathrm{P}$ concentrations (Mann-Whitney, $\mathrm{p}<0.05$ ), between monocots and dicots. In the dry season, there were significant differences in $\mathrm{CP}, \mathrm{NDF}, \mathrm{Ca}, \mathrm{Na}$, and $\mathrm{P}$ concentrations (Mann-Whitney, $\mathrm{p}<0.05$ ) between monocots and dicots. In the wet season, between monocots and dicots, there were significant differences in $\mathrm{Ca}$, and $\mathrm{Na}$ concentrations (Mann-Whitney, $\mathrm{p}<0.05$ ). The concentrations of ADL, Na, K, and P (Mann-Whitney, $\mathrm{p}<0.05)$ in monocots and dicots differed significantly between the dry and wet seasons.

The top model selection for forage consumption revealed that throughout the year and in the dry season, ADL concentration influenced forage use by mega and meso-herbivores, excluding elephant, whose forage use was influenced by NDF concentration (Supplementary Table S11). In the wet season, AC and ADL concentrations influenced the major forage use. The correlogram revealed that throughout the year, rhino significantly consumed forage with low $\mathrm{CP}$ and ADL concentrations; elephant significantly consumed forage rich in NDF and low in $\mathrm{Ca}, \mathrm{Na}$, and $\mathrm{P}$; and buffalo, swamp deer, and hog deer significantly consumed forage with low ADL content (Fig. 5a). In the dry season, rhino significantly consumed forage with low CP; elephant significantly consumed forage rich in NDF and low in Na and P; buffalo and swamp deer significantly consumed forage with low $\mathrm{CP}, \mathrm{ADL}$, and $\mathrm{Ca}$; and hog deer significantly consumed forage with low ADL concentration (Fig. 5b). In the wet season, rhino, buffalo, swamp deer, hog deer, and sambar significantly consumed forage with low ADL concentration, whereas elephant significantly consumed forage with low AC (Fig. 5c).

\section{Discussion}

With their large body size, the rhino and elephant require almost $150 \mathrm{~kg}$ and $240 \mathrm{~kg}$ of fodder, respectively, every day, and thus spend most of their time foraging ${ }^{41,49,52}$. Mega and meso-herbivores consumed more monocots in the wet season than in the dry season, although the swamp deer consistently consumed more monocots than 
other herbivores species. An increase in graze from the dry to the wet season has been recorded in different studies, which also reported 22 to 283 forage plants in the diet of rhino ${ }^{18,44}, 46$ to 112 forage plants in the diet of elephant ${ }^{18,53,54}, 183$ forage plants in the diet of buffalo ${ }^{48}, 13$ to 42 forage plants in the diet of swamp deer ${ }^{2,29,50}$, and 15 to 20 forage plants in the diet of hog deer ${ }^{29,55}$. The diet of sambar is flexible and changes according to the availability of forage ${ }^{56,57}$ and studies have recorded 15 to 180 forage plants in the diet of sambar ${ }^{50,58}$.

In the present study, 124 forage plants in the diet of rhino were recorded of which 69 were identified up to species level and 55 were identified as monocots and dicots. For the elephant, 105 forage plants were recorded in the diet, of which 67 were identified up to species and 38 only as monocots and dicots. For buffalo, 96 forage plants were recorded in diet, of which 62 were identified up to species and 34 only as monocots and dicots. For swamp deer, 90 forage plants were recorded in the diet, of which 59 were identified up to species and 31 only as monocots and dicots. For hog deer, 91 forage plants were recorded in the diet, of which 59 were identified up to species and 32 were only identified as monocots and dicots. For sambar, 92 forage plants were recorded in the diet, of which 63 were identified up to species and remaining 29 only as monocots and dicots. BEN shows that in both the dry and wet seasons, graminoids constituted $50 \%$ or more of the diet of both mega and mesoherbivores and Poaceae and Cyperaceae as the most recorded families. In the family Poaceae, the tall grass Saccharum spp. was dominant, which might be because of its availability throughout the year. The diet of swamp deer and hog deer had more of the short grass species $H$. compressa in the dry season and more of the tall grass species Saccharum spp. in the wet season. C. tenuis (family Arecaceae) was mostly consumed by elephant, the possible reason for this could be their ability to exploit resources that are not accessible to other species studied in the area because of its trunk.

We could not detect the presence of important fodder species such as Mallotus philippinensis in the diet of any of our study species, even though they were common in the study area and the evidence of browsing on it was observed. In other studies, in similar habitats, its presence could not be detected in the diet of elephant, swamp deer, and hog deer through faecal analysis (e.g., Pradhan et al. ${ }^{18}$, Wegge et al. ${ }^{29}$, and Steinheim et al. ${ }^{59}$ ). This is an inherent problem in the feeding habit study using micro-histological methods. Further, we failed to detect the presence of Bombax ceiba, another common species in the area, though elephants eat its bark. In several other studies (e.g., Brahmachary et $\mathrm{al}^{45}$, and $\mathrm{Patar}^{47}$ ), it was concluded that the large herbivores do not eat $B$. ceiba leaves but debarking, particularly by elephants, is a common feature. A major proportion of the unidentified dicot forage in the diet thus can be attributed to woodland species like M. philippinensis, Terminalia spp., Syzygium fruticosum, Mangifera indica, and Ficus spp. These are the reported forage species for rhino and elephant ${ }^{18,29,41,43,59}$.

Experimental studies conducted in North America and Europe showed that mega-herbivores meet their physiological needs by feeding more on dominant species. In high productive ecosystems, this favors plant diversity, whereas in low productive ecosystems, this negatively affects plant diversity ${ }^{60}$. In contrast, selective feeding by meso-herbivores negatively affects plant diversity ${ }^{61}$. Therefore, feeding choices, population, and physiological demand of mega and meso-herbivores can alter the vegetation composition ${ }^{62}$. The present study revealed that throughout the year, among dicot plants, $Z$. jujuba was mostly consumed by both mega and meso-herbivores. Similarly, among monocot plants, Saccharum spp. was largely consumed by rhino, elephant, buffalo, and sambar throughout the year. Whereas, $H$. compressa was largely consumed by swamp deer, and hog deer. This suggests the dependence of mega and meso-herbivores on these particular dicots and monocots. The nutrient analysis of major forage also revealed that the major forage species consumed throughout the year by mega and mesoherbivores were more nutritious in the wet season. In the future, any changes in the availability, accessibility, and nutrient content of the major forage plants might affect the population of these mega and meso-herbivores. Therefore, further experimental studies explaining the factors responsible for feeding choices as well as the impact of mega and meso-herbivores on plant vegetation are required, to understand the community vegetation dynamics in KNP.

\section{Conclusions and conservation implications}

The information on the diet composition provides insight into the feeding habits of the mega and meso-herbivores in the wet grasslands of the Brahmaputra floodplains. The findings of this study support the hypothesis that both mega and meso-herbivores consumed a more graze-based diet in the wet season than in the dry season $\left(\mathrm{H}_{1}\right)$. The mega and meso-herbivores grazed more during the wet season, although browse also formed a significant portion of the diet; indicating that both mega and meso-herbivores were grazers and mixed feeders. As monocots were found to be dominant in the forage of rhino, buffalo, swamp deer, and hog deer throughout the year, these species may be more involved in grazing during both the dry and wet seasons. The herbivores, while foraging on nutrient-rich forage, might consume chemically defended forage, resulting in the consumption of toxic plant secondary metabolites (tannins and polyphenols). The detoxification of the secondary metabolites requires more energy. Therefore, to avoid toxic plant secondary metabolites, herbivores might feed on low nutrient quality forage $^{63}$. The shifting of elephant and sambar in the wet season from browsing to grazing indicates their flexibility in utilization of the available forage. The availability of green and nutrient-rich forage is due to the higher moisture regime and controlled burning of wet grasslands. This could be the reason why mega and meso-herbivores feed more on monocots in the wet season ${ }^{18}$. The present study also supports the hypothesis of more nutritious principal monocot forage in the wet season $\left(\mathrm{H}_{2}\right)$. Compared to other herbivores, the diet of rhino, elephant, and sambar consisted more of browse. This contradicts the Jarman-Bell principle, according to which large-bodied herbivores feed mostly on less nutritious graminoids. The seasonal changes in forage availability, mouth size, gut physiology, and predation risk might be responsible for the differences in the forage consumption among mega and meso-herbivores as observed in other studies (e.g., Pradhan et al. ${ }^{18}$, Wegge et al. ${ }^{29}$, Steinheim et al. ${ }^{59}$ ).

The study suggests that tall and short grasses play a crucial role in meeting the dietary requirements of both mega and meso-herbivores and the importance of riverine alluvial floodplain grasslands in conserving the mega 
and meso-herbivores. In KNP, the ongoing processes of succession and invasion threaten the grasslands, which in the future might affect the availability of the principal forage plants consumed by mega and meso-herbivores. Thus, grassland-based effective management interventions for conserving the crucial habitat of mega and mesoherbivores are suggested. In the climate crisis and habitat degradation era, the present study will help Park managers to formulate effective conservation strategies for conserving mega and meso-herbivores.

\section{Materials and methods}

Study area. KNP, in the north-eastern Indian state of Assam, is situated in the floodplains of the Brahmaputra River, which runs along the northern boundary of the Park; and the Karbi Anglong Hills form the southern boundary. KNP, with an area of $429.93 \mathrm{~km}^{2}$, lies between latitudes $26^{\circ} 34^{\prime} \mathrm{N}$ and $26^{\circ} 46^{\prime} \mathrm{N}$ and longitudes $93^{\circ} 08^{\prime} \mathrm{E}$ and $93^{\circ} 36^{\prime} \mathrm{E}$ (Fig. 1). An effort to conserve the rhino started with the declaration of Kaziranga as a Reserve Forest in 1908. It was later declared a Wildlife Sanctuary in 1950 and upgraded to a National Park in 1974. Subsequently, it was declared a UNESCO World Heritage Site in 1985 and a Tiger Reserve in $2007^{64}$. After more than 100 years of conservation efforts, the population of the wildlife in the area has increased ${ }^{64}$. KNP, with its flat terrain and rich alluvial soil, is characterized by numerous permanent water bodies, locally known as beels. The climate is of the typical subtropical monsoon type. The total annual precipitation in the study area varies from 1592.8 to $2247.8 \mathrm{~mm}$ (2011-2015, Assam Forest Department) with a mean annual precipitation at $1802.7 \pm 118.5 \mathrm{~mm}$.

Floods from the Brahmaputra River play a crucial role in the maintenance of the wet grassland ecosystem in KNP, which largely constitutes of tall grasses, short grasses, wetlands, and semi-evergreen forests ${ }^{65}$, and supports one of the world's largest population of rhino and buffalo, and significant populations of the Eastern swamp deer and elephant ${ }^{64}$. KNP is home to eight mega and meso-herbivores, viz. R. unicornis, E. maximus, B. arnee, Bos gaurus, $R$. duvaucelii, A. porcinus, $R$. unicolor, and Muntiacus muntjak ${ }^{66}$.

Food habit study. The micro-histological analysis was used to study the feeding habits of the mega and meso-herbivores ${ }^{2,29,55,67}$. This technique involves the preparation of reference slides from the plant material (leaf, stems, flower, and fruit) and comparing it with the slides prepared from the known faecal samples of mega and meso-herbivores ${ }^{29,68}$. The microscopic identification of forage plant fragments was carried out using the keys from Satkopan ${ }^{69}$ and Johnson et al. ${ }^{70}$. For reference samples, 75 potential forage plants were collected from the field, based on literature review and direct field observations ${ }^{2,29,67}$ (Supplementary Table S12). The taxonomic identification of reference plant materials was based on flora of the Kaziranga and Manas National Parks ${ }^{71-73}$. The samples were oven-dried at $60{ }^{\circ} \mathrm{C}$ for $48 \mathrm{~h}^{74}$, stored in labelled paper bags, and brought to the headquarter for laboratory analysis. The reference samples were processed using the micro-histological technique ${ }^{29}$ in the laboratory (Fig. 6a).

Seventy-five potential forage plants belonging to 31 families were collected. Twenty-eight percent $(n=21)$ of these were monocots, and $72 \%(\mathrm{n}=54)$ were dicots. Among the six growth forms, $17.33 \%(\mathrm{n}=13)$ were grasses, $8 \%(n=6)$ were sedges, $6.66 \%(n=5)$ were climbers, $44 \%(n=33)$ were herbs, $17.33 \%(n=13)$ were shrubs, and $6.66 \%(n=5)$ were trees. Of these 75 forage plants, $42.67 \%(n=32)$ were collected from short grasslands, $29.33 \%$ $(\mathrm{n}=22)$ from tall grasslands and $28 \%(\mathrm{n}=21)$ from woodlands (Supplementary Table S12).

Fresh dung samples of mega-herbivores, viz. rhino, elephant and buffalo, and pellets of the meso-herbivores, viz. swamp deer, hog deer, and sambar, were collected each month from November 2013 to April 2015 (excluding the flood period from June till October, during which Park remains closed and sample collection was not possible $)^{64,75}$. For the elephant, buffalo, swamp deer, hog deer, and sambar, the faecal samples were collected opportunistically, whereas, for rhino, the faecal samples were collected from latrine sites ${ }^{76}$. These faecal samples were collected from random locations in the short and tall grasslands and woodlands within three forest ranges of KNP, namely Kohora (central), Agoratoli (eastern), and Bagori (western) (Supplementary Table S13). Overall, 1975 faecal samples were collected for both mega and meso-herbivores, of which 1500 samples were collected in the dry season (from November to March) and 475 samples in the wet season (April to May) (Supplementary Table S14). For mega-herbivores, a fresh dung sample, weighing about 400 gm was collected ${ }^{29,59}$. Based on the study by Jachmann and Bell ${ }^{77}$, which showed a positive linear relationship between elephant size, and weight and circumference of boli (individual faeces), we used boli as a guideline for elephant dung sample collection to ensure representation from varied body size individuals ${ }^{59}$. The faecal samples collected from randomly selected habitats within similar locations and ranges were used to make composite samples. For mega-herbivores, five dung samples collected from the same location on the same date were selected randomly and mixed thoroughly to make one composite sample. From this composite sample, $25 \mathrm{~g}$ of grounded dung sample was used for microhistological analysis following Wegge et al. ${ }^{29}$. Similarly, five faecal pellets of the meso-herbivores from each five randomly collected pellet samples were pooled together to make one composite sample. The composite samples were processed using the micro-histological technique following Wegge et al. ${ }^{29}$

Five slides were prepared from each composite sample. Seventy composite samples and 350 slides each were prepared (no. of observations, $n=3500$ ) for rhino and elephant. Sixty-five composite samples and 325 slides each were prepared for buffalo, swamp deer, and hog deer $(n=3250)$, and 60 composite samples and 300 slides were prepared for sambar $(n=3000)$. Observations with at least two identifiable fragments were considered for the detection of forage plant species consumed. Whenever possible, identification up to species level was attempted by comparing each sample with the reference plant samples that included leaf, stems, flower, and fruit. We have taken only leaves, stems, flower, and fruit for the preparation of reference materials, and not the bark or roots. Fragments with identifiable features where identification up to species or genus level was difficult due to damaged fragments were categorized as unidentified monocots (including Bambusa spp.), and unidentified dicots (including M. philippinensis, Terminalia spp., and S. fruticosum) ${ }^{18}$. 


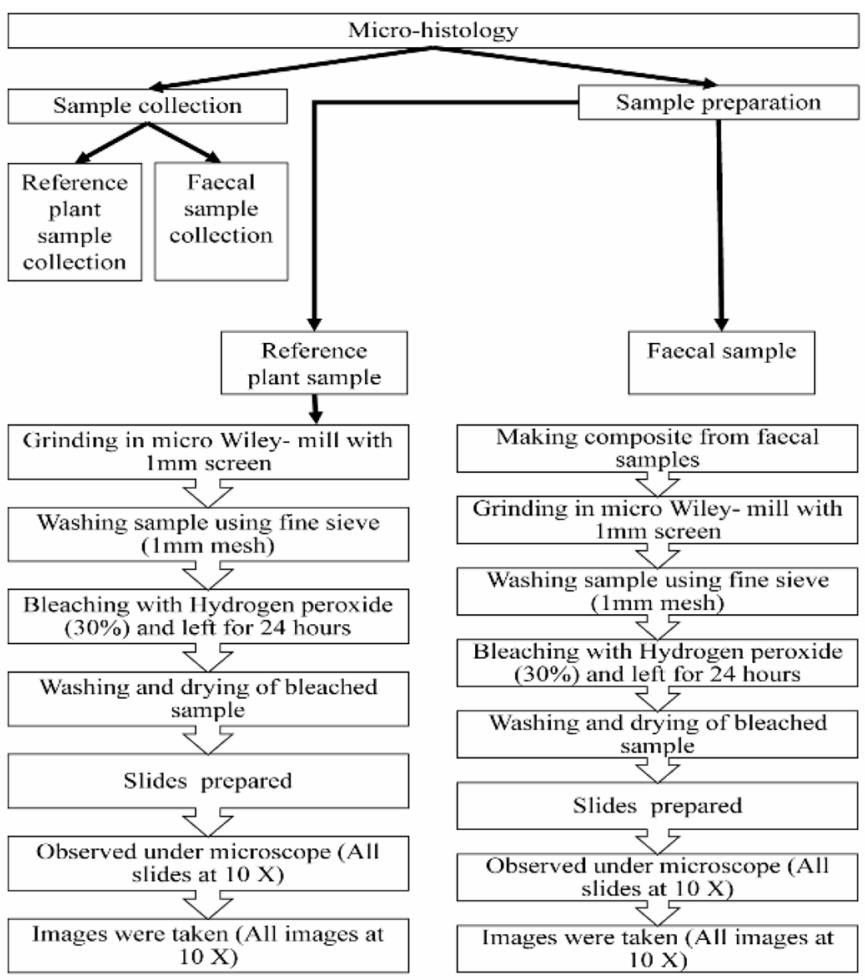

(a)

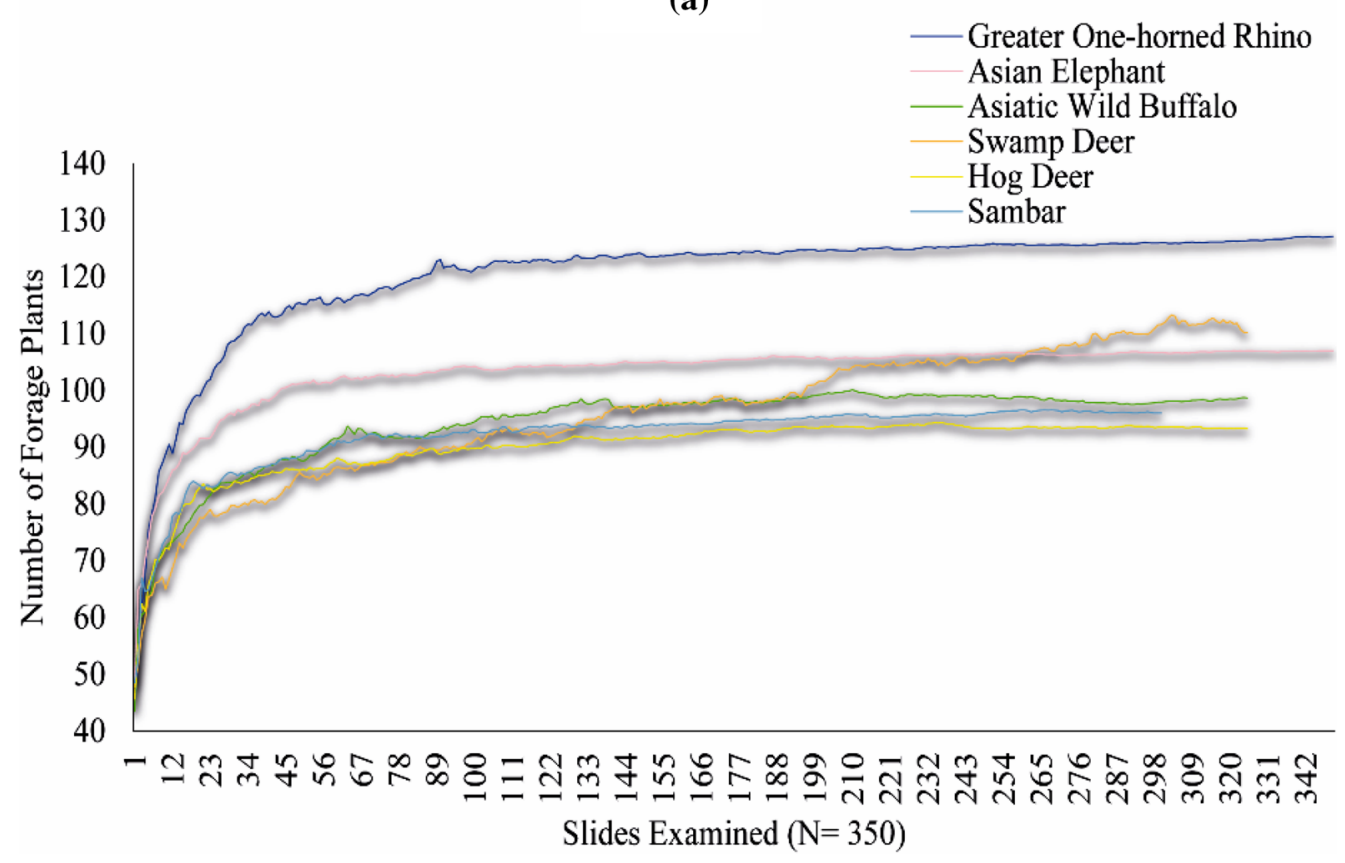

(b)

Figure 6. Graph showing (a) pathway for micro-histological analysis of plant reference samples and faecal samples and (b) overall species accumulation curve for mega and meso-herbivores (Greater one-horned rhino and Asian elephant: $\mathrm{N}=350$; Asiatic wild buffalo, swamp deer and hog deer: $\mathrm{N}=325$; sambar: $\mathrm{N}=300$ ).

The species accumulation curve was asymptotic at a sample size below the number of slides examined, indicating a sufficient sample size (Fig. 6b). Overall, rhino utilized the maximum number of forage species ( $\mathrm{n}=124$, including both identified and unidentified plants), followed by elephant $(\mathrm{n}=105)$, buffalo $(\mathrm{n}=96)$, sambar $(n=92)$, hog deer $(n=91)$, and swamp deer $(n=90)$ (Table 1$)$. 
Forage quality. Based on the results from the micro-histological analysis, the forage plants consumed in the highest proportion by mega and meso-herbivores were collected twice every month from November 2015 to May 2016. These samples were oven-dried at $60^{\circ} \mathrm{C}$ for $48 \mathrm{~h}$ in the field and finely ground in $1 \mathrm{~mm}$ mesh screen of a Cyclotech's micro-Wiley mill and stored in airtight plastic bags for estimation of CP, AC, fibre (NDF, ADF, and $\mathrm{ADL}$ ), and minerals ( $\mathrm{Ca}, \mathrm{P}, \mathrm{Mg}, \mathrm{K}$, and $\mathrm{Na}$ ). Standard protocols were followed to estimate nutrient content (Supplementary Table S15). For Ca and Mg estimation, AAnalyst 700 Atomic Absorption Spectrometer was used with MERCK Certipur Single-Element Standards of Ca and Mg. Similarly, for P estimation, the SMART Spectro 2 Spectrophotometer was used with standard phosphate solution $\left(\mathrm{KH}_{2} \mathrm{PO}_{4}\right)^{78}$.

Data analysis. To determine the diet composition of mega and meso-herbivores more precisely, the forage plants identified were categorized further on the basis of (1) graze-to-browse ratio (on monocot and dicot consumption), (2) growth form (grass, sedge, herb, shrub, climber and tree), (3) family, and (4) species. The percentage occurrence of each forage type (graze-to-browse, growth form, family, and species) in the diet of mega and meso-herbivores was determined using the equation of Sparks and Malechek ${ }^{68}$ and Tuboi and Hussain ${ }^{55}$ :

$$
\% \text { contribution of forage plants }=\frac{\text { Number of identifiable fragments of each category }}{\text { Total number of identifiable fragments of all plant species }} \times 100 \text {. }
$$

A species accumulation curve was plotted to determine the sampling effort required to adequately examine the diet composition of mega and meso-herbivores. EstimateS version 9 with a $95 \%$ confidence interval was used to produce the species accumulation curve $\mathrm{e}^{79}$. The number of slides examined and the forage plants identified from the faecal samples of the mega and meso-herbivores were plotted in the species accumulation curve ${ }^{80}$. The dietary spectrum of the mega and meso-herbivores was obtained to visualize the pattern of forage utilization on the basis of the major contributing plants. The chi-square test of association and Fisher's Exact Test were carried out to identify seasonal differences in the forage consumed between the mega and meso-herbivores and among the six herbivores. The tests were performed using SPSS version 22. BEN was used to visualize the forage utilization by mega and meso-herbivores, using R package "bipartite" version $2.11^{81}$. The forage plants were grouped by family, and only the top 20 abundant families, contributing more than $80 \%$ to the diet of mega and meso-herbivores, were highlighted and the rest of the families were grouped under the other category.

The seasonal differences in the nutrient content of major monocot and dicot forage plants were analyzed using a non-parametric Mann-Whitney $U$-test in SPSS version 22. The effect of nutrient factor (predictor) on the use of major forage plants (response) was modelled using a generalized linear model (GLM) and Pearson's correlation analysis. For GLM, R package "MuMin" vers.1.43.17 and for correlogram, R package "Hmisc" vers. 4.4-0 and "corrplot" vers. 0.84 were used ${ }^{82-84}$.

Statement for handling plants/plant materials. Experimental research and field studies including collection of plant/plant material for this study, is compliant with the relevant institutional, national, and international guidelines and legislations. The biological samples examined were collected with the permission from the Principal Chief Conservator of Forest (Wildlife) \& Chief Wildlife Warden, Government of Assam under section 12 of the Indian Wild Life (Protection) Act, 1972 in O.O No. 868 dated 20th August, 2013. A permission was also obtained from the Director, Kaziranga National Park, Assam in KNP/FG647WII/Research dated 31st October, 2013.

Ethics approval. Experimental research and field studies including collection of plant/plant material for this study, is compliant with the relevant institutional, national, and international guidelines and legislations.

Received: 20 March 2021; Accepted: 13 December 2021

Published online: 10 January 2022

\section{References}

1. Krebs, C. J. Ecological Methodology 2nd edn. (Addison Welsey Educational Publishers Inc, 1999).

2. Tewari, R. \& Rawat, G. S. Studies on the food and feeding habits of Swamp Deer (Rucervus duvaucelii duvaucelii) in Jhilmil Jheel conservation reserve, Haridwar, Uttarakhand, India. ISRN Zool. 2013, 1-6. https://doi.org/10.1155/2013/278213 (2013).

3. Brodeur, R. D., Smith, B. E., McBride, R. S., Heintz, R. \& Farley, E. New perspectives on the feeding ecology and trophic dynamics of fishes. Environ. Biol. Fishes. 100, 293-297. https://doi.org/10.1007/s10641-017-0594-1 (2017).

4. Vesey-FitzGerald, D. F. Grazing succession among East African game animals. J. Mammal. 41, 161-172. https://doi.org/10.2307/ 1376351 (1960).

5. Lamprey, H. F. Ecological separation of the large mammal species in the Tarangire game reserve, Tanganyika. Afr. J. Ecol. 1, 63-92. https://doi.org/10.1111/j.1365-2028.1963.tb00179.x (1963).

6. Ahrestani, F. S. Asian Eden Large Herbivore Ecology in India (Wageningen University, 2009).

7. Bell, R. H. V. The use of herb layer by grazing ungulates in the Serengeti. In Animal Populations in Relation to their Food Resources (eds. Watson, A.) 111-124 (Blackwell Science, 1970).

8. Jarman, P. The social organisation of antelopes in relation to their ecology. Behaviour 48, 215-267. https://doi.org/10.1163/15685 3974X00345 (1974).

9. Hofmann, R. R. \& Stewart, D. R. M. Grazer of browser: A classification based on the stomach structure and feeding habits of East African ruminants. Mammalia 36, 226-240 (1972).

10. Bell, R. H. V. A grazing ecosystem in the Serengeti. Sci. Am. 225, 86-93 (1971).

11. Kleiber, M. The Fire of Life. An Introduction to Animal Energetics (Krieger, 1932). 
12. Demment, M. W. \& Van Soest, P. J. A nutritional explanation for body-size patterns of ruminant and nonruminant herbivores. Am. Nat. 125, 641-672. https://doi.org/10.1086/284369 (1985).

13. Hofmann, R. R. The Ruminant Stomach: Stomach Structure and Feeding Habits of East African Game Ruminants. East African Monograph in Biology, vol. 2, 1-364 (E.A. Lit. Bureau, 1973).

14. Ahrestani, F. S., Heitkönig, I. M., Matsubayashi, H. \& Prins, H. H. Grazing and browsing by large herbivores in South and Southeast Asia. In The Ecology of Large Herbivores in South and Southeast Asia, (eds. Ahrestani, F. S. \& Sankaran, M.) 99-120. (Springer, 2016).

15. Geist, V. On the relationship of social evolution and ecology in Ungulates. Am. Zool. 14, 205-220. https://doi.org/10.1093/icb/ 14.1.205 (1974).

16. Clauss, M., Steuer, P., Müller, D. W. H., Codron, D. \& Hummel, J. Herbivory and body size: Allometries of diet quality and gastrointestinal physiology, and implications for herbivore ecology and dinosaur gigantism. PLoS One 8, e68714. https://doi.org/10. 1371/journal.pone.0068714 (2013)

17. Ahrestani, F. S., Heitkönig, I. M. \& Prins, H. H. Diet and habitat-niche relationships within an assemblage of large herbivores in a seasonal tropical forest. J. Trop. Ecol. 28, 385-394. https://doi.org/10.1017/S0266467412000302 (2012).

18. Pradhan, N. M., Wegge, P., Moe, S. R. \& Shrestha, A. K. Feeding ecology of two endangered sympatric mega-herbivores: Asian elephant Elephas maximus and greater one-horned rhinoceros Rhinoceros unicornis in lowland Nepal. Wildl. Biol. 14, 147-154. https://doi.org/10.2981/0909-6396(2008)14[147:feotes]2.0.co;2 (2008).

19. McNaughton, S. J. \& Georgiadis, N. J. Ecology of African grazing and browsing mammals. Annu. Rev. Ecol. Syst. 17, 39-66. https:// doi.org/10.1146/annurev.es.17.110186.000351 (1986).

20. Owen-Smith, R. N. Adaptive Herbivore Ecology: From Resources to Populations in Variable Environments. Adaptive Herbivore Ecology (Cambridge University Press, 2002). https://doi.org/10.1017/CBO9780511525605.

21. Olff, H., Ritchie, M. E. \& Prins, H. H. T. Global environmental controls of diversity in large herbivores. Nature 415, 901-904. https://doi.org/10.1038/415901a (2002).

22. Bailey, D. W. \& Provenza, F. D. Mechanisms determining large-herbivore distribution. In Resource Ecology, vol. 23 (eds. Prins, H. H. T. \& Van Langevelde, F.) 7-28 (Springer, 2008). https://doi.org/10.1007/978-1-4020-6850-8_2.

23. Prins, H. H. T. \& Van Langevelde, F. Assembling a diet from different places. In Resource Ecology, vol. 23 (eds. Prins, H. H. T. \& Van Langevelde, F.) 129-155 (Springer, 2008). https://doi.org/10.1007/978-1-4020-6850-8_12.

24. Fryxell, J. M. et al. Landscape scale, heterogeneity, and the viability of Serengeti grazers. Ecol. Lett. 8, 328-335. https://doi.org/10. 1111/j.1461-0248.2005.00727.x (2005).

25. Du Toit, J., Rogers, K. \& Biggs, H. The Kruger Experience: Ecology and Management of Savanna Heterogeneity, vol. 29 (Island Press, 2003).

26. Ripple, W. J. et al. Collapse of the world's largest herbivores. Sci. Adv. 1, e1400103. https://doi.org/10.1126/sciadv.1400103 (2015).

27. Menon, V. Indian Mammals: A Field Guide. (Hachette India, 2014).

28. Reddy, C. S., Jha, C. S., Diwakar, P. G. \& Dadhwal, V. K. Nationwide classification of forest types of India using remote sensing and GIS. Environ. Monit. Assess. 187, 777. https://doi.org/10.1007/s10661-015-4990-8 (2015).

29. Wegge, P., Shrestha, A. K. \& Moe, S. R. Dry season diets of sympatric ungulates in lowland Nepal: Competition and facilitation in alluvial tall grasslands. Ecol. Res. 21, 698-706. https://doi.org/10.1007/s11284-006-0177-7 (2006).

30. WWF. Living Planet: Report 2016. Risk and Resilience in a New Era. (World Wide Fund for Nature International, 2016).

31. Gebremedhin, B. et al. DNA metabarcoding reveals diet overlap between the endangered walia ibex and domestic goats: Implications for conservation. PLoS One 11, e0159133. https://doi.org/10.1371/journal.pone.0159133 (2016).

32. Spooner, F. E., Pearson, R. G. \& Freeman, R. Rapid warming is associated with population decline among terrestrial birds and mammals globally. Glob. Change Biol. 24, 4521-4531. https://doi.org/10.1111/gcb.14361 (2018).

33. Texeira, M., Baldi, G. \& Paruelo, J. An exploration of direct and indirect drivers of herbivore reproductive performance in arid and semi-arid rangelands by means of structural equation models. J. Arid Environ. 81, 26-34. https://doi.org/10.1016/j.jaridenv. 2012.01.017 (2012).

34. Kupika, O. L., Gandiwa, E., Kativu, S. \& Nhamo, G. Impacts of climate change and climate variability on wildlife resources in southern Africa: Experience from selected protected areas in Zimbabwe. In Selected Studies in Biodiversity, (eds. Şen, B. \& Grillo, O.) 1-23 (IntechOpen, 2018). https://doi.org/10.5772/intechopen.70470.

35. Joyce, C. B., Simpson, M. \& Casanova, M. Future wet grasslands: Ecological implications of climate change. Ecosyst. Health Sustain. 2, e01240. https://doi.org/10.1002/ehs2.1240 (2016).

36. Vasu, N. K., \& Singh, G. Grasslands of Kaziranga National Park: Problems and approaches for management. In Ecology and Management of Grassland Habitats in India, vol. 17 (eds. Rawat, G. S., Adhikari, B. S.) 104-113 (Wildlife Institute of India, 2015).

37. Dublin, H. T. Vegetation dynamics in the Serengeti-Mara ecosystem: The role of elephants, fire, and other factors. In Serengeti II: Dynamics, Management, and Conservation of an Ecosystem, (eds. Sinclair, A. R. E. \& Arcese, P.) 71-90 (University of Chicago Press, 1995).

38. Sinclair, A. R. E. Equilibria in plant-herbivore interactions. In Serengeti II: Dynamics, Management, and Conservation of an Ecosystem, (eds. Sinclair, A. R. E. \& Arcese, P.) 91-113 (University of Chicago Press, 1995).

39. Augustine, D. J. \& McNaughton, S. J. Ungulate effects on the functional species composition of plant communities: Herbivore selectivity and plant tolerance. J. Wildl. Manag. 62, 1165. https://doi.org/10.2307/3801981 (1998).

40. Schmitt, M. H. \& Shrader, A. M. Browser population-woody vegetation relationships in Savannas. In Savanna Woody Plants and Large Herbivores (eds. Scogings, F. P. \& Sankaran, M.) 245-278 (Wiley, 2020). https://doi.org/10.1002/9781119081111.ch9.

41. Konwar, P., Saikia, M. K. \& Saikia, P. K. Abundance of food plant species and food habits of Rhinoceros unicornis Linn. in Pobitora Wildlife Sanctuary, Assam, India. J. Threat. Taxa. 1, 457-460. https://doi.org/10.11609/jott.o1640.457-60 (2009).

42. Bhatta, R. Ecology and Conservation of Great Indian One-horned Rhino (Rhinoceros unicornis) in Pobitora Wildlife Sanctuary, Assam, India (Gauhati University, 2011).

43. Hazarika, B. C. \& Saikia, P. K. Food habit and feeding patterns of great indian one-horned rhinoceros (Rhinoceros unicornis) in Rajiv Gandhi Orang National Park, Assam, India. ISRN Zool. 2012, 1-11. https://doi.org/10.5402/2012/259695 (2012).

44. Dutta, D. K., Bora, P. J., Mahanta, R., Sharma, A. \& Swargowari, A. Seasonal variations in food plant preferences of reintroduced Rhinos Rhinoceros unicornis (Mammalia: Perrissodactyla: Rhinocerotidae) in Manas National Park, Assam, India. J. Threat. Taxa. 8, 9525-9536. https://doi.org/10.11609/jott.2486.8.13.9525-9536 (2016).

45. Brahmachary, R. L., Rakshit, B. \& Mallik, B. Further attempts to determine the food habits of the Indian Rhinoceros at Kaziranga. J. Bombay Nat. Hist. Soc. 71, 295-299 (1974).

46. Banerjee, G. Habitat Use by the Great Indian Rhinoceros (Rhinoceros Unicornis) and Other Sympatric Large Herbivores in Kaziranga National Park, Assam, India (Wildlife Institute of India, 2001).

47. Patar, K. C. Behavioural Patterns of the One Horned Indian Rhinoceros (Spectrum Publication Guwahati, 2005).

48. Bawri, M. \& Saikia, P. K. Preliminary study on the food plant species of Endangered Asiatic wild water buffalo Bubalus arnee Kerr in Kaziranga National Park, Assam India. NeBIO. 5, 49-55 (2014).

49. Sukumar, R. Ecology of the Asian elephant in southern India. I. Movement and habitat utilization patterns. J. Trop. Ecol. 5, 1-18. https://doi.org/10.1017/S0266467400003175 (1989).

50. Schaller, G. B. The Deer and the Tiger. A Study of Wildlife in India, (University of Chicago Press, 1967). https://doi.org/10.7208/ chicago/9780226736570.001.0001. 
51. Dhungel, S. K. \& O’Gara, B. W. Ecology of the Hog Deer in Royal Chitwan National Park, Nepal. Wildl. Monogr. 119, 3-40. https:// doi.org/10.2307/3830632 (1991).

52. Johnsingh, A. J. T. \& Manjrekar, N. Mammals of South Asia, 2 (Universities Press, 2016)

53. Sukumar, R. Ecology of the Asian elephant in southern India. II. Feeding habits and crop raiding patterns. J. Trop. Ecol. 6, 33-53. https://doi.org/10.1017/S0266467400004004 (1990).

54. Baskaran, N., Balasubramanian, M., Swaminathan, S. \& Desai, A. A. Feeding ecology of the Asian elephant Elephas maximus Linnaeus in the Nilgiri Biosphere Reserve, southern India. J. Bombay Nat. Hist. Soc. 107, 3-13 (2010).

55. Tuboi, C. \& Hussain, S. A. Factors affecting forage selection by the endangered Eld's deer and hog deer in the floating meadows of Barak-Chindwin Basin of North-east India. Mamm. Biol. 81, 53-60. https://doi.org/10.1016/j.mambio.2014.10.006 (2016).

56. Kelton, S. D. \& Skipworth, J. P. Food of sambar deer (Cervus unicolor) in a Manawatu (New Zealand) flax swamp. N. Z. J. Ecol. 10, 149-152 (1987).

57. Semiadi, G., Barry, T. N., Muir, P. D. \& Hodgson, J. Dietary preferences of sambar (Cervus unicolor) and red deer (Cervus elaphus) offered browse, forage legume and grass species. J. Agric. Sci. 125, 99-107. https://doi.org/10.1017/S0021859600074554 (1995).

58. Johnsingh, A. J. T. \& Sankar, K. Food plants of chital, sambar and cattle on Mundanthurai Plateau, Tamil Nadu, south India. Mammalia 55, 57-66. https://doi.org/10.1515/mamm.1991.55.1.57 (1991).

59. Steinheim, G., Wegge, P., Fjellstad, J. I., Jnawali, S. R. \& Weladji, R. B. Dry season diets and habitat use of sympatric Asian elephants (Elephas maximus) and greater one-horned rhinoceros (Rhinocerus unicornis) in Nepal. J. Zool. 265, 377-385. https://doi.org/10. 1017/S0952836905006448 (2005).

60. Bakker, E. S., Ritchie, M. E., Olff, H., Milchunas, D. G. \& Knops, J. M. H. Herbivore impact on grassland plant diversity depends on habitat productivity and herbivore size. Ecol. Lett. 9, 780-788. https://doi.org/10.1111/j.1461-0248.2006.00925.x (2006).

61. Edwards, G. R. \& Crawley, M. J. Herbivores, seed banks and seedling recruitment in mesic grassland. J. Ecol. 87, 423-435. https:// doi.org/10.1046/j.1365-2745.1999.00363.x (1999).

62. Marquis, R. J. The role of herbivores in terrestrial trophic cascades. In: Trophic Cascades: Predators, Prey and the Changing Dynamics of Nature, (eds. Terborgh, J. \& Estes, J. A.) 109-123, (Island Press, 2010).

63. Parikh, G. L. et al. The influence of plant defensive chemicals, diet composition, and winter severity on the nutritional condition of a free-ranging, generalist herbivore. Oikos 126, 1-8. https://doi.org/10.1111/oik.03359 (2017).

64. Yadava, M. K. Kaziranga National Park: Detailed Report on Issues and Possible Solutions of Long-Term Protection of the Greater One-horned Rhinoceros in Kaziranga National Park Pursuant to the Order of the Hon'ble Guwahati High Court. 1-402 (Government of Assam, India, 2014).

65. Champion, H. G. \& Seth, S. K. A Revised Survey of the Forest Types of India (Govt. of India Press, 1968).

66. Sharma, G. Studies on the mammalian diversity of Kaziranga National Park, Assam, India with their conservation status. J. New Biol. Rep. 7, 15-19 (2018).

67. Shrestha, R., Wegge, P. \& Koirala, R. A. Summer diets of wild and domestic ungulates in Nepal Himalaya. J. Zool. 266, 111-119. https://doi.org/10.1017/S0952836905006527 (2005).

68. Sparks, D. R. \& Malechek, J. C. Estimating percentage dry weight in diets using a microscopic technique. J. Range Manag. 21, 264-265. https://doi.org/10.2307/3895829 (1968).

69. Satkopan, S. Key to identification of plant remains in animal dropping. J. Bombay Nat. Hist. Soc. 69, 139-150 (1972).

70. Johnson, M. K., Wofford, H. H. \& Pearson, H. A. Microhistological Techniques for Food Habits Analyses (U.S. Department of Agriculture, 1983).

71. Jain, S. K. \& Hajra, P. K. On the botany of Manas Wild Life Sanctuary in Assam. Bull. Bot. Surv. Ind. 17, 75-86 (1975).

72. Hajra, P. K. \& Jain, S. K. Botany of Kaziranga and Manas (Surya International Publications, 1994).

73. Rahmani, A. R., Kasambe, R., Prabhu, S., Khot, R. \& Bajaru, S. Biodiversity Studies at Kaziranga National Park. (2016).

74. Vila, A. R., Galende, G. I. \& Pastore, H. Feeding ecology of the endangered huemul (Hippocamelus bisulcus) in Los Alerces National Park, Argentina. Mastozool. Neotrop. 16, 423-431 (2009).

75. Borah, S. B., Sivasankar, T., Ramya, M. N. S. \& Raju, P. L. N. Flood inundation mapping and monitoring in Kaziranga National Park, Assam using Sentinel-1 SAR data. Environ. Monit. Assess. https://doi.org/10.1007/s10661-018-6893-y (2018).

76. De Barba, M. et al. Comparing opportunistic and systematic sampling methods for non-invasive genetic monitoring of a small translocated brown bear population. J. Appl. Ecol. 47, 172-181. https://doi.org/10.1111/j.1365-2664.2009.01752 (2010).

77. Jachmann, H. \& Bell, R. H. V. The use of elephant droppings in assessing numbers, occupance and age structure: A refinement of the method. Afr. J. Ecol. 22, 127-141. https://doi.org/10.1111/j.1365-2028.1984.tb00686.x (1984).

78. Chaturvedi, R. K. \& Sankar, K. Laboratory Manual for the Physico-Chemical Analysis of Soil, Water and Plant (Wildlife Institute of India, 2006).

79. Colwell, R. K. \& Elsensohn, J. E. EstimateS turns 20: Statistical estimation of species richness and shared species from samples, with non-parametric extrapolation. Ecography 37, 609-613. https://doi.org/10.1111/ecog.00814 (2014).

80. Colwell, R. K. et al. Models and estimators linking individual-based and sample-based rarefaction, extrapolation and comparison of assemblages. J. Plant Ecol. 5, 3-21. https://doi.org/10.1093/jpe/rtr044 (2012).

81. Dormann, C. F., Gruber, B. \& Fründ, J. Introducing the bipartite package: Analysing ecological networks. R News 8, 8-11 (2008).

82. Barton, K. \& Barton, M. K. Package 'MuMIn'. R package version, 1 (2019).

83. Harrell Jr, F. E. \& Harrell Jr, M. F. E. Package 'Hmisc'. CRAN2018, 2019, 235-236 (2019).

84. Wei, T. et al. Package 'corrplot': Visualization of a correlation matrix. Statistician 56, 316-324 (2017).

\section{Acknowledgements}

This study was funded by the Department of Science and Technology, Government of India (Grant No. SR/ SO/AS-28/2012) through the project entitled "Pattern of biomass production by wetlands and its use by wild ungulates in Kaziranga landscape". We are grateful to the Department of Environment and Forests, Assam for granting us permission to carry out this research. We express our sincere gratitude to Mr. N. K. Vasu and Mr. M. K. Yadava, former Park Directors, Kaziranga National Park for their support in the field. We thank Mr. Seal Sharma, former Divisional Forest Officer, Kaziranga National Park and Shri Rabindra Kumar Sharma, Research Officer, Kaziranga National Park for facilitating the fieldwork. We thank the Director and the Dean at the Wildlife Institute of India for providing logistic support and encouragement. We thank Dr. Chongpi Tuboi and Dr. K. Muthamizh Selvan for helping us at the initial stage of the fieldwork, Zeeshan Ali for preparing the maps, and Amanat Kaur Gill for help in editing the manuscript.

\section{Author contributions}

S.A.H. developed the concept, raised funds and design the research methods. A.D. and M.S. collected the field data. A.D. conducted the experiment and analyzed the data. R.B. and G.G.V. facilitated the field data collection. A.D. and S.A.H. wrote the manuscript. A.D., S.A.H., M.S. and R.B. reviewed and edited the manuscript. 


\section{Competing interests}

The authors declare no competing interests.

\section{Additional information}

Supplementary Information The online version contains supplementary material available at https://doi.org/ 10.1038/s41598-021-04295-4.

Correspondence and requests for materials should be addressed to S.A.H.

Reprints and permissions information is available at www.nature.com/reprints.

Publisher's note Springer Nature remains neutral with regard to jurisdictional claims in published maps and institutional affiliations.

(c) (1) Open Access This article is licensed under a Creative Commons Attribution 4.0 International License, which permits use, sharing, adaptation, distribution and reproduction in any medium or format, as long as you give appropriate credit to the original author(s) and the source, provide a link to the Creative Commons licence, and indicate if changes were made. The images or other third party material in this article are included in the article's Creative Commons licence, unless indicated otherwise in a credit line to the material. If material is not included in the article's Creative Commons licence and your intended use is not permitted by statutory regulation or exceeds the permitted use, you will need to obtain permission directly from the copyright holder. To view a copy of this licence, visit http://creativecommons.org/licenses/by/4.0/.

(c) The Author(s) 2022 